\title{
Nature and Types of Abusive Behavior against Women
}

\author{
Nahida M. Aljanabi*
}

Athra'a Karim Hussein AL-Bahadli**

\begin{abstract}
Background and Objectives: A wide range of studies show that women who have experienced physical or sexual abuse. Therefore, the present study aims to assess the nature and common types of abusive behaviors (physical\& psychological) which are imposed up on the women in Bab- Al-Moudham center and to find the relationship of such behaviors with the woman's demographic characteristics.

Material and Method: A descriptive study was conducted in Bab- Al-Moudham center in Baghdad city during the period from $15^{\text {th }}$ July to30 $0^{\text {th }}$ September 2011.

A convenient (non probability) sample of (200) women at age(20) years and older was selected. The data was collected through the constructed questionnaire and interview technique was employed for the purpose of the study. Data were analyzed through frequency, percentage, chi- square, use cut of point and scoring level: physical abuse $\backslash$ high 14, moderate 11-13, low 8-10, psychological abuse $\backslash$ high 20 , moderate 16-19, low11-15.
\end{abstract}

Results: Distribution of demographic characteristics showed that the greater number of these women were( 20-24) years old, college graduate, not work, married and coming out from extended family, abusers consanguinity was the husband.

Conclusions: The study concluded that most of the women were exposed to some extent of abusive behaviors and the most common ones were screaming and yelling.

Keywords: nature, types, abusive, behaviors, women.

\section{INTRODUCTION}

Violence against women is any act of gender- based violence that results in, or is likely to result in physical or sexual or psychological harm or suffering to women including threats of such acts, coercion, or arbitrary, whether in public or private place. World wide, one of the most common forms of violence against women is abuse by their husbands or other intimate partners (WHO, 2011; Lundwall, 2009). A wide range of studies show that women who have experienced physical or sexual abuse, whether in childhood or adulthood, are at greater risk of subsequent health problem. Violence has been linked to many serious health problems, both immediate and long- term, these include physical health problems, such as injury, chronic pain syndromes, and gastrointestinal disorders, and range of mental health problems, including anxiety and depression. Violence also undermines health by increasing a variety of negative behaviors, such as smoking, alcohol and drug abuse (Dickinson, 1999).

Violence kills women. World wide, an estimated $40 \%$ to over $70 \%$ of homicides of women are committed by intimated partners, often in the context of an abusive relationship (Gilbert, 1995).

Most abused women are not passive victims but use active strategies to maximize their safety and that of their children. Some women resist, others flee, and still others attempt to keep the peace by capitulating to their husband's demands, what may seem to an observer to be lack of response to living with violence may in fact be strategic assessment of what it takes for the women to survive in the marriage and to protect herself and her children. A woman's response to abuse is often limited by the options available to her. Women consistently cite similar reasons that they remain in abusive relationships: fear of retribution, lack of other means of economic support concern for the children, emotional dependence, lack of support from family and friends, and an abiding hope that" he will change". In developing countries women cite the un acceptability of being single or unmarried as an additional barrier that keeps them in destructive marriages (Basemore, 2002).

The main ideology of Islam with regard to the status of women is that women should be equal to men in rights and responsibilities. This is reflected in the marriage contract that

* Professor/PhD/College of Health and Medical Technology/Baghdad/Foundation of Technical Education

** Assistant Lecturer/MSc Community Health department/College of Health and Medical Technology/Baghdad/Foundation of Technical Education/Baghdad/Iraq 
necessitates the consent of both the bride and bridegroom. The two contracting partners have equal rights to continue the relationship or nullify the contract or divorce. In so far as the man is concerned, this is termed Talaq (divorce). In so far as the woman is concerned, this is termed Khula.3 Islam outlines detailed rules concerning the building of marriage contracts and subsequently terminating them. Islam has endowed upon women several rights. Some of these rights are: to retain her maiden name after marriage and to maintain and carry out her financial or business income independently. Islam also allows women to keep their nationality, keep custody of children after divorce and it obligates the husband to pay alimony (family support). There are several versions in the Qur'an and Hadith4 that stress on the rights of women. The following section clarifies the causes of the overlapping cultures of the Muslim countries with the teachings of Islam with regard to women's Rights (Baobaid, 2002).

\section{RESULTS}

Table(1): Distribution of women's demographic characteristics.

\begin{tabular}{|l|c|c|}
\hline $\begin{array}{c}\text { Demographic } \\
\text { characteristic }\end{array}$ & frequency & \% \\
\hline 1-women's age & 57 & 28.5 \\
\hline $20-24$ & 30 & 15 \\
\hline $25-29$ & 37 & 18.5 \\
\hline $30-34$ & 31 & 15.5 \\
\hline $35-39$ & 45 & 22.5 \\
\hline 40 and above & f. & $\mathbf{\%}$ \\
\hline 2-Educational level & 50 & 25 \\
\hline $\begin{array}{l}\text { 1-college graduate and } \\
\text { over }\end{array}$ & 40 & 20 \\
\hline 2-Institute graduate & 22 & 11 \\
\hline $\begin{array}{l}\text { 3-Secondary } \\
\text { graduate }\end{array}$ & 21 & 10.5 \\
\hline $\begin{array}{l}\text { 4-Intermediate school } \\
\text { graduate }\end{array}$ & 37 & 18.5 \\
\hline 5-Primary school graduate & 12 & 6 \\
\hline 6-Able to read and write & 18 & 9 \\
\hline 7-Illiterate & f. & $\mathbf{\%}$ \\
\hline 3-Occupation status & 73 & 36.5 \\
\hline 1-Work & 127 & 63.5 \\
\hline 2-Not work & f. & $\mathbf{\%}$ \\
\hline 4-Marital status & & \\
\hline
\end{tabular}

\section{MATERIAL AND METHOD}

A descriptive cross- sectional study to assess the most common types of abuse that imposed up on women in Bab- Al-Moudham center in Baghdad city during the period from $15^{\text {th }}$ July to $30^{\text {th }}$ September 2011. A convenient( non- probability) sample of 200 women at age of 20 years and older was selected. The data was collected through constructed questionnaire and interview technique was employed for the purpose of the study. The questionnaire was comprised of two main parts. The first part included the demographical characteristics which were related to the sample of the study. The second part consisted of questions related to the nature and type of abusive behavior physical and psychological. Frequency, percentage, chisquare, montocarlo test, use of cut of point at $90^{\text {th }}$ percent, $50^{\text {th }}$ percent and $30^{\text {th }}$ percent by using percentile were used for statistical analysis. The coring level were as the following; physical abuse $\backslash$ high 14, moderate 11-13, low 8-10, psychological abuse $\backslash$ high 20, moderate 16-19, low11-15.

\begin{tabular}{|l|c|c|}
\hline 1-Single & 54 & 27 \\
\hline 2-Married & 126 & 63 \\
\hline 3-Divorced & 7 & 3.5 \\
\hline 4-widow & 13 & 6.5 \\
\hline 5-Auser's consanguinity & f. & $\mathbf{\%}$ \\
\hline 1-Husband & 127 & 63.5 \\
\hline 2-Father & 46 & 23 \\
\hline 3-Brother & 23 & 11.5 \\
\hline 4-Son & 4 & 2 \\
\hline
\end{tabular}

Table(2): Distribution of women according to physical abuse as nature and type of abusive behavior.

\begin{tabular}{|l|c|c|c|c|}
\hline \multicolumn{1}{|c|}{ physical abuse } & Yes & $\mathbf{\%}$ & No & $\mathbf{\%}$ \\
\hline 1-Hits with fist & 65 & 32.5 & 135 & 67.5 \\
\hline $\begin{array}{l}\text { 2- Hits with nearst } \\
\text { objects }\end{array}$ & 40 & 20 & 160 & 80 \\
\hline $\begin{array}{l}\text { 3- Hits with lethal } \\
\text { weapon }\end{array}$ & 0 & 0 & 200 & 100 \\
\hline 4-Slapping and & 81 & 40.5 & 119 & 59.5 \\
\hline $\begin{array}{l}\text { 5-Pushing } \\
\text { shaking }\end{array}$ & 38.5 & 123 & 61.5 \\
\hline 6-Kick's with feet & 14 & 7 & 186 & 93 \\
\hline 7-Burning & 3 & 1.5 & 197 & 98.5 \\
\hline
\end{tabular}


Table (3): Distribution of women according to psychological abuse as type and nature of abusive behavior

\begin{tabular}{|l|c|c|c|c|}
\hline Psychological abuse & Yes & $\mathbf{\%}$ & No & $\mathbf{\%}$ \\
\hline 1-Screaming and yelling & 149 & 74.5 & 51 & 25.5 \\
\hline 2-Lock up indoors & 52 & 26 & 148 & 74 \\
\hline 3-Belittling & 61 & 30.5 & 139 & 69.5 \\
\hline 4-Criticizing & 118 & 59 & 82 & 41 \\
\hline 5-Negligence & 69 & 34.5 & 131 & 65.5 \\
\hline 6-Name calling & 42 & 21 & 158 & 79 \\
\hline 7-Intimidation & 96 & 48 & 104 & 52 \\
\hline 8-Humiliation & 57 & 28.5 & 143 & 71.5 \\
\hline 9-Coercive sex & 46 & 23 & 154 & 77 \\
\hline 10-Monitoring her movement & 45 & 22.5 & 155 & 77.5 \\
\hline 11-Restricting her assess to resources & 61 & 30.5 & 139 & 69.5 \\
\hline
\end{tabular}

Table (4): Association between age of the women according to physical and psychological abuse.

\begin{tabular}{|l|c|c|c|c|}
\hline \multirow{2}{*}{ Age } & \multicolumn{3}{|c|}{ Physical score } & \multirow{2}{*}{ Total } \\
\cline { 2 - 4 } & L(8-10) & M(11-13) & H(>14) & \\
\hline \multirow{2}{*}{$\mathbf{( 2 0 - 2 9 )}$} & 12 & 21 & 55 & 88 \\
& $13.6 \%$ & $23.9 \%$ & $62.5 \%$ & $100.0 \%$ \\
\hline \multirow{2}{*}{$\mathbf{3 0 - 3 9 )}$} & 19 & 19 & 31 & 69 \\
& $27.5 \%$ & $27.5 \%$ & $44.9 \%$ & $100.0 \%$ \\
\hline \multirow{2}{*}{$\mathbf{( 4 0 - 5 0 )}$} & 7 & 16 & 20 & 43 \\
& $16.3 \%$ & $37.2 \%$ & $46.5 \%$ & $100.0 \%$ \\
\hline \multirow{2}{*}{ Total } & 38 & 56 & 106 & 200 \\
& $19.0 \%$ & $28.0 \%$ & $53.0 \%$ & $100.0 \%$ \\
\hline
\end{tabular}

$\mathbf{P}>\mathbf{0 . 0 5}$ (NS)

\begin{tabular}{|l|c|c|c|c|}
\hline \multirow{2}{*}{ Age } & \multicolumn{3}{|c|}{ Psychological score } & \multirow{2}{*}{ Total } \\
\cline { 2 - 4 } & L(11-15) & M(16-19) & H(>20) & \\
\hline \multirow{2}{*}{$\mathbf{( 2 0 - 2 9 )}$} & 12 & 36 & 40 & 88 \\
& $13.6 \%$ & $40.9 \%$ & $45.5 \%$ & $100.0 \%$ \\
\hline \multirow{2}{*}{$\mathbf{( 3 0 - 3 9 )}$} & 18 & 28 & 23 & 69 \\
& $26.1 \%$ & $40.6 \%$ & $33.3 \%$ & $100.0 \%$ \\
\hline \multirow{2}{*}{$\mathbf{( 4 0 - 5 0 )}$} & 8 & 22 & 13 & 43 \\
& $18.6 \%$ & $51.2 \%$ & $30.2 \%$ & $100.0 \%$ \\
\hline \multirow{2}{*}{ Total } & 38 & 86 & 76 & 200 \\
& $19.0 \%$ & $43.0 \%$ & $38.0 \%$ & $100.0 \%$ \\
\hline
\end{tabular}

$\mathbf{P}>\mathbf{0 . 0 5}$ (NS)

Table (5): Association between education level according to physical and psychological abuse.

\begin{tabular}{|c|c|c|c|c|}
\hline \multirow{2}{*}{ Education } & \multicolumn{3}{|c|}{ Physical score } & \multirow{2}{*}{ Total } \\
\hline & L (8-10) & $M(11-13)$ & $\mathbf{H}(>14)$ & \\
\hline 1-college graduate and over & $\begin{array}{c}4 \\
7.8 \%\end{array}$ & $\begin{array}{c}12 \\
23.5 \%\end{array}$ & $\begin{array}{c}35 \\
68.6 \%\end{array}$ & $\begin{array}{c}51 \\
100.0 \%\end{array}$ \\
\hline 2-Institute graduate & $\begin{array}{c}3 \\
7.7 \%\end{array}$ & $\begin{array}{c}13 \\
33.3 \%\end{array}$ & $\begin{array}{c}23 \\
59.0 \%\end{array}$ & $\begin{array}{c}39 \\
100.0 \%\end{array}$ \\
\hline 3-Secondary school graduate & $\begin{array}{c}2 \\
9.1 \% \\
\end{array}$ & $\begin{array}{c}5 \\
22.7 \% \\
\end{array}$ & $\begin{array}{c}15 \\
68.2 \% \\
\end{array}$ & $\begin{array}{c}22 \\
100.0 \%\end{array}$ \\
\hline 4-Intermediate school graduate & $\begin{array}{c}8 \\
38.1 \%\end{array}$ & $\begin{array}{c}7 \\
33.3 \%\end{array}$ & $\begin{array}{c}6 \\
28.6 \%\end{array}$ & $\begin{array}{c}21 \\
100.0 \%\end{array}$ \\
\hline 5-Primary school graduate & $\begin{array}{c}12 \\
32.4 \% \\
\end{array}$ & $\begin{array}{c}10 \\
27.0 \% \\
\end{array}$ & $\begin{array}{c}15 \\
40.5 \% \\
\end{array}$ & $\begin{array}{c}37 \\
100.0 \% \\
\end{array}$ \\
\hline 6-Able to read and write illiterate & $\begin{array}{c}5 \\
41.7 \%\end{array}$ & $\begin{array}{c}2 \\
16.7 \%\end{array}$ & $\begin{array}{c}5 \\
41.7 \%\end{array}$ & $\begin{array}{c}12 \\
100.0 \%\end{array}$ \\
\hline 7- Illiterate & $\begin{array}{c}4 \\
22.2 \%\end{array}$ & $\begin{array}{c}7 \\
38.9 \% \\
\end{array}$ & $\begin{array}{c}7 \\
38.9 \% \\
\end{array}$ & $\begin{array}{c}18 \\
100.0 \%\end{array}$ \\
\hline Total & $\begin{array}{c}38 \\
19.0 \%\end{array}$ & $\begin{array}{c}56 \\
28.0 \%\end{array}$ & $\begin{array}{c}106 \\
53.0 \%\end{array}$ & $\begin{array}{c}200 \\
100.0 \%\end{array}$ \\
\hline
\end{tabular}

MCP $<0.01$ (HS) 


\begin{tabular}{|l|c|c|c|c|}
\hline \multirow{2}{*}{ Education } & \multicolumn{3}{|c|}{ psychological score } & \multirow{2}{*}{ Total } \\
\cline { 2 - 5 } & L(11-15) & M(16-19) & H(>20) & \\
\hline \multirow{2}{*}{ 1-college graduate and over } & 7 & 15 & 29 & 51 \\
& $13.7 \%$ & $29.4 \%$ & $56.9 \%$ & $100.0 \%$ \\
\hline \multirow{2}{*}{ 2-Institute graduate } & 3 & 21 & 15 & 39 \\
& $7.7 \%$ & $53.8 \%$ & $38.5 \%$ & $100.0 \%$ \\
\hline \multirow{2}{*}{ 3-Secondary school graduate } & 1 & 8 & 13 & 22 \\
& $4.5 \%$ & $36.4 \%$ & $59.1 \%$ & $100.0 \%$ \\
\hline \multirow{2}{*}{ 4-Intermediate school graduate } & 8 & 8 & 5 & 21 \\
& $38.1 \%$ & $38.1 \%$ & $23.8 \%$ & $100.0 \%$ \\
\hline \multirow{2}{*}{ 5-Primary school graduate } & 12 & 16 & 9 & 37 \\
& $32.4 \%$ & $43.2 \%$ & $24.3 \%$ & $100.0 \%$ \\
\hline \multirow{2}{*}{ 6-Able to read and write illiterate } & 5 & 4 & 3 & 12 \\
& $41.7 \%$ & $33.3 \%$ & $25.0 \%$ & $100.0 \%$ \\
\hline \multirow{2}{*}{ 7- Illiterate } & 2 & 14 & 2 & 18 \\
& $11.1 \%$ & $77.8 \%$ & $11.1 \%$ & $100.0 \%$ \\
\hline \multirow{2}{*}{ Total } & 38 & 86 & 76 & 200 \\
& $19.0 \%$ & $43.0 \%$ & $38.0 \%$ & $100.0 \%$ \\
\hline
\end{tabular}

MCP $<0.01$ (HS)

Table (6): Association between occupation according to physical and psychological abuse.

\begin{tabular}{|l|c|c|c|c|}
\hline \multirow{2}{*}{ Occupation } & \multicolumn{3}{|c|}{ Physical score } & \multirow{2}{*}{ Total } \\
\cline { 2 - 4 } Work & $\mathbf{L ( 8 - 1 0 )}$ & $\mathbf{M}(\mathbf{1 1 - 1 3})$ & $\mathbf{H}>\mathbf{( 1 4 )}$ & \\
\hline \multirow{2}{*}{ Not work } & 6 & 18 & 49 & 73 \\
& $8.2 \%$ & $24.7 \%$ & $67.1 \%$ & $100.0 \%$ \\
\hline \multirow{2}{*}{ Total } & 32 & 38 & 57 & 127 \\
& $25.2 \%$ & $29.9 \%$ & $44.9 \%$ & $100.0 \%$ \\
\hline & 38 & 56 & 106 & 200 \\
& $19.0 \%$ & $28.0 \%$ & $53.0 \%$ & $100.0 \%$ \\
\hline
\end{tabular}

\begin{tabular}{|l|c|c|c|c|}
\hline \multicolumn{4}{|c|}{ P<0.01 (HS) } & \multicolumn{4}{|c|}{} & \multirow{2}{*}{ Potal } \\
\hline \multirow{2}{*}{ Occupation } & \multicolumn{3}{|c|}{ Psychological score } & \\
\cline { 2 - 4 } & L(11-15) & M(16-19) & H(>20) & \\
\hline \multirow{2}{*}{ Work } & 8 & 28 & 37 & 73 \\
& $11.0 \%$ & $38.4 \%$ & $50.7 \%$ & $100.0 \%$ \\
\hline \multirow{2}{*}{ Not work } & 30 & 58 & 39 & 127 \\
& $23.6 \%$ & $45.7 \%$ & $30.7 \%$ & $100.0 \%$ \\
\hline \multirow{2}{*}{ Total } & 38 & 86 & 76 & 200 \\
& $19.0 \%$ & $43.0 \%$ & $38.0 \%$ & $100.0 \%$ \\
\hline
\end{tabular}

$\mathbf{P}<0.01$ (HS)

Table (7): Association between marital status according to physical and psychological abuse.

\begin{tabular}{|l|c|c|c|c|}
\hline \multirow{2}{*}{ Marital status } & \multicolumn{3}{|c|}{ Physical score } & \multirow{2}{*}{ Total } \\
\cline { 2 - 4 } & $\mathbf{L}(\mathbf{8 - 1 0})$ & $\mathbf{M}(\mathbf{1 1 - 1 3})$ & $\mathbf{H}(\mathbf{1 4 )}$ & \\
\hline \multirow{2}{*}{ 1-Single } & 34 & 39 & 51 & 124 \\
& $27.4 \%$ & $31.5 \%$ & $41.1 \%$ & $100.0 \%$ \\
\hline \multirow{2}{*}{ 2-Married } & 3 & 11 & 42 & 56 \\
& $5.4 \%$ & $19.6 \%$ & $75.0 \%$ & $100.0 \%$ \\
\hline \multirow{2}{*}{ 3-Divorced } & 1 & 4 & 3 & 8 \\
& $12.5 \%$ & $50.0 \%$ & $37.5 \%$ & $100.0 \%$ \\
\hline \multirow{2}{*}{ 4-Widow } & 0 & 2 & 10 & 12 \\
& $.0 \%$ & $16.7 \%$ & $83.3 \%$ & $100.0 \%$ \\
\hline \multirow{2}{*}{ Total } & 38 & 56 & 106 & 200 \\
& $19.0 \%$ & $28.0 \%$ & $53.0 \%$ & $100.0 \%$ \\
\hline
\end{tabular}

$\mathrm{MCP}<0.01$ (HS) 


\begin{tabular}{|l|c|c|c|c|}
\hline \multirow{2}{*}{ Marital status } & \multicolumn{3}{|c|}{ psychological score } & \multirow{2}{*}{ Total } \\
\cline { 2 - 4 } & $\mathbf{L ( 1 1 - 1 5 )}$ & $\mathbf{M}(\mathbf{1 6 - 1 9})$ & $\mathbf{H}(>\mathbf{2 0})$ & \\
\hline \multirow{2}{*}{ 1- Single } & 24 & 55 & 45 & 124 \\
& $19.4 \%$ & $44.4 \%$ & $36.3 \%$ & $100.0 \%$ \\
\hline \multirow{2}{*}{ 2-Married } & 8 & 20 & 28 & 56 \\
& $14.3 \%$ & $35.7 \%$ & $50.0 \%$ & $100.0 \%$ \\
\hline \multirow{2}{*}{ 3-Divorced } & 2 & 6 & 0 & 8 \\
& $25.0 \%$ & $75.0 \%$ & $.0 \%$ & $100.0 \%$ \\
\hline \multirow{2}{*}{ 4-Widow } & 4 & 5 & 3 & 12 \\
& $33.3 \%$ & $41.7 \%$ & $25.0 \%$ & $100.0 \%$ \\
\hline \multirow{2}{*}{ Total } & 38 & 86 & 76 & 200 \\
& $19.0 \%$ & $43.0 \%$ & $38.0 \%$ & $100.0 \%$ \\
\hline
\end{tabular}

MCP> 0.05 (NS)

Table (8): Association between family type according to physical and psychological abuse.

\begin{tabular}{|l|c|c|c|c|}
\hline \multirow{2}{*}{ Family type } & \multicolumn{3}{|c|}{ Physical score } & \multirow{2}{*}{ Total } \\
\cline { 2 - 4 } & $\mathbf{L ( 8 - 1 0 )}$ & $\mathbf{M}(\mathbf{1 1 - 1 3})$ & $\mathbf{H}(>\mathbf{1 4})$ & \\
\hline \multirow{2}{*}{ 1-Nuclear } & 18 & 22 & 54 & 94 \\
& $19.1 \%$ & $23.4 \%$ & $57.4 \%$ & $100.0 \%$ \\
\hline \multirow{2}{*}{ 2-Extended } & 20 & 34 & 52 & 106 \\
& $18.9 \%$ & $32.1 \%$ & $49.1 \%$ & $100.0 \%$ \\
\hline \multirow{2}{*}{ Total } & 38 & 56 & 106 & 200 \\
& $19.0 \%$ & $28.0 \%$ & $53.0 \%$ & $100.0 \%$ \\
\hline
\end{tabular}

$\mathrm{P}>0.05$ (NS)

\begin{tabular}{|l|c|c|c|c|}
\hline \multirow{2}{*}{ Family type } & \multicolumn{3}{|c|}{ psychological score } & \multirow{2}{*}{ Total } \\
\cline { 2 - 4 } & L(11-15) & M(16-19) & H(>20) & \\
\hline \multirow{2}{*}{ 1-Nuclear } & 15 & 39 & 40 & 94 \\
& $16.0 \%$ & $41.5 \%$ & $42.6 \%$ & $100.0 \%$ \\
\hline \multirow{2}{*}{ 2-Extended } & 23 & 47 & 36 & 106 \\
& $21.7 \%$ & $44.3 \%$ & $34.0 \%$ & $100.0 \%$ \\
\hline \multirow{2}{*}{ Total } & 38 & 86 & 76 & 200 \\
& $19.0 \%$ & $43.0 \%$ & $38.0 \%$ & $100.0 \%$ \\
\hline
\end{tabular}

$\mathbf{P}>0.05$ (NS)

Table (9): Association between abuser's consanguinity of women according to physical and psychological abuse.

\begin{tabular}{|l|c|c|c|c|}
\hline \multirow{2}{*}{ Abuser's consanguinity } & \multicolumn{3}{|c|}{ Physical score } & \multirow{2}{*}{ Total } \\
\cline { 2 - 5 } & $\mathbf{L ( 8 - 1 0 )}$ & $\mathbf{M}(\mathbf{1 1 - 1 3})$ & $\mathbf{H}(>\mathbf{1 4})$ & \\
\hline \multirow{2}{*}{ 1-Husband } & 35 & 42 & 54 & 131 \\
& $26.7 \%$ & $32.1 \%$ & $41.2 \%$ & $100.0 \%$ \\
\hline \multirow{2}{*}{ 2-Father } & 2 & 5 & 34 & 41 \\
& $4.9 \%$ & $12.2 \%$ & $82.9 \%$ & $100.0 \%$ \\
\hline \multirow{2}{*}{ 3-Brother } & 1 & 9 & 13 & 23 \\
& $4.3 \%$ & $39.1 \%$ & $56.5 \%$ & $100.0 \%$ \\
\hline \multirow{2}{*}{ 4-Son } & 0 & 0 & 5 & 5 \\
& $.0 \%$ & $.0 \%$ & $100.0 \%$ & $100.0 \%$ \\
\hline \multirow{2}{*}{ Total } & 38 & 56 & 106 & 200 \\
& $19.0 \%$ & $28.0 \%$ & $53.0 \%$ & $100.0 \%$ \\
\hline
\end{tabular}

$\mathrm{MCP}<0.01$ (HS) 


\begin{tabular}{|l|c|c|c|c|}
\hline \multirow{2}{*}{ Abuser's consanguinity } & \multicolumn{3}{|c|}{ psychological score } & \multirow{2}{*}{ Total } \\
\cline { 2 - 4 } & L(11-15) & $\mathbf{M}(\mathbf{1 6 - 1 9 )}$ & $\mathbf{H}(\mathbf{2 0})$ & \\
\hline \multirow{2}{*}{ 1-Husband } & 25 & 60 & 46 & 131 \\
& $19.1 \%$ & $45.8 \%$ & $35.1 \%$ & $100.0 \%$ \\
\hline \multirow{2}{*}{ 2-Father } & 6 & 11 & 24 & 41 \\
& $14.6 \%$ & $26.8 \%$ & $58.5 \%$ & $100.0 \%$ \\
\hline \multirow{2}{*}{ 3-Brother } & 5 & 12 & 6 & 23 \\
\multirow{2}{*}{ 4-Son } & $21.7 \%$ & $52.2 \%$ & $26.1 \%$ & $100.0 \%$ \\
\hline \multirow{2}{*}{ Total } & 2 & 3 & 0 & 5 \\
& $40.0 \%$ & $60.0 \%$ & $.0 \%$ & $100.0 \%$ \\
\hline
\end{tabular}

\section{$\mathrm{MCP}>0.05$ (NS)}

\section{DISCUSSION}

Violence against women has been recognized as an important social and human rights issue that affects all cultures and societies (Moore, 2008).

Throughout the course of data analysis of the present study, the findings of the study showed that the greater number of the women was between (20-24) years old and they were accounted for $(28.5 \%)$. With respect to educational level on quarter of women were college graduate, while $(63.5 \%)$ of them were not work, $(63 \%)$ of the sample were married, more than one half of the women were coming from extended family, (63.5\%) of women were abused by their husbands. This data is in line with study conducted by Gossaye et. al. (2003) who reported that 3000 women more than two thirds of respondent who suffered domestic violence were below 35 years of age with mean age \& standard deviation(SD) of $29.87 \pm 9.24$ years (Gossaye et. al., 2003).

Alhabib et.al. (2009) reported that a total of 134 studies in England on the prevalence of domestic violence against women, the majority of the studies were conducted in North America (41\%) followed by Europe (20\%) especially women aged 18-65 years, but excluding women with specific disabilities or diseases (Alhabib et.al., 2009).

Johnson, et.al. (2003) stated that $(95 \%$ response rate) of domestic violence with highest in the age group(26-30) years (Johnson, et.al., 2003). Goodwin and others(2000) who considered a higher rate of abuse were reported by women who were younger and less educated (Johnson et.al., 2003). The study conducted by Ezegwui and others (2003) who found that $(17.7 \%)$ financial problems, $(4.4 \%)$ un employment, were the risk factors for being the victim of domestic abuse to total of 424 women (Ezegwui et. al., 2003).

Levinson analysis of ethnographic data from 90 peasant and small- scale societies indicates that in $86 \%$ of these there is violence against wives by husbands (Levinson, 1989). The result from the feasibility study in Butajira conducted in January 2000. Husbands usually are the perpetrators of physical violence against married women (Moore, 2008; Gossaye et. al., 2003).

Poverty and oppression are cited as being significant factors in violence behavior, low income with subsequent stress and limited resources add to the potential for violence (Gelles, 1995; Hanrahan, 2000). Johnson, et. al. (2003) concluded from their study that the prevalence of domestic violence was $(17 \%)$ in the North of England punching and slapping were the common pattern of violence, and $(10 \%)$ of women experiencing domestic violence had forced sexual activity (Johnson et.al., 2003).

Gossaye et. al. (2003) reported that over 3000 women $(49 \%)$ of them suffered from physical violence, the common form of violence are beating with stick; forceful slap to the face; burn with flaming sticks; kicking; beatings with fists or house hold objects. Wife battering is one of the most common forms of domestic violence that occur in the home context (Gossaye et. al., 2003).

Yoshi Hama and Sorenson(1994) stated that the greatly accounted one was for psychological- abuse- yelling and screaming(184) women, while burning in physical abuse took the lowest account(6) women (Yoshi, 1994).

The finding of the present study revealed that there were no significant differences between age of women and abusive behaviors imposed against the women. The finding of this study 
coincide with a survey conducted by Hassan and others (2002) who stated that a sample consisting of 300 individuals with equal presentation of male and female participants most often experience intimate violence were middle- aged group(31-40) years female and(21-30) years for male (Hassan, et. al., 2002).

There were statistically a significant association between educational level and abusive behaviors against the women. The findings of the study coincide with Khairi (2006) and AlBadayneh (2012) reported that women with higher and lower educational level were significant association between types of domestic violence( physical, psychological and sexual) and educational level except social domestic violence (Khairi, 2006; AlBadayneh, 2012).

Kuning et. al. (2004) who stated that physical abuse was associated with parity, marital status, and length of relationship (Kuning, 2004).

Finally, the results of the study indicate that there were significant differences between physical abuse and abuser's consanguinity of women and no significant association with psychological abuse.

In the United States, a women is beaten every 18 minutes. Domestic violence is the leading cause of injury among women of reproductive age in United States (Anonymous, 1996a). Besides this results there was at least one in six wives is hit a husband sometimes during their relationship (Stuart, 2001).

\section{CONCLUSION}

The study concludes that most of the women were exposed to some extent of abusive behaviors and the most common one's were screaming and yelling. Most of abusers were spouses. Abuse was greatly associated with young college graduate, not work, and living in extended family.

\section{RECOMMENDATIONS}

The present study recommends that a considerable attention is needed from the health care to stress on questioning the women on such behaviors during their visits to the health centers seeking for health care, due to it direct effect on their physical and psychological wellbeing. Further studies are recommended to determine the contribution of these factors to the presence of such stressful behaviors.

\section{REFERENCES}

AlBadayneh MD. (2012). Violence Against women in Jordan.J Fam Viol. 27. P.p.
369-379. IVSL (Iraqi Virtual Scientific Library).

Alhabib S, Nur U, Jones R. (2010). Domestic violence against women: Systematic Review of prevalence studies. J Fam Viol. 25. P.p. 369-382. IVSL (Iraqi Virtual Scientific Library).

Anonymous. (1996a). Women and violence. United Nations- Department of Public Information.

Baobaid M. (2002). Access to women abuse services by Arab- speaking Muslim women in London, Ontario. Background Investigation and Recommendations for further Research and community Outreach. Center for Research on violence against women and children.

Basemore G and Griffiths CT. (2002). Conference, circles, boards, and mediations: Scouting the new wave of community justice decision making approaches. Retrieved from http://www. cjprimer.com/circles.htm=all on 2012.

Dickinson LM, Degruy FV, Dickinson WP, Candib LM. (1999). Health- related quality of life and symptom profiles of female survivors of sexual abuse. Archives of family medicine. 8(1). P.p. 35-43.

Ezegwui UH, Ikeme CA, Onwasigwe NC. (2003). Domestic Violence Against Pregnant Women. Tropical Journal of Obstetric and Cynaecology. 20. P.p.116118.

Gelles R. (1995). Contemporary Families: A sociological view. Thousand Oaks, CA: Sage.

Gilbert L. (1995). Urban violence and health, South Africa. Social science and medicine. 43(5). P.p. 873-886.

Goodwin M, Gazmararian JA, Gohnson CH, Gilbert BC, Saltzman LA. (2000). Pregnancy intendedness and physical abuse around risk assessment monitoring system.1996-1997 Health J. 4(2). P.p. 85-92.

Gossaye Y, Deyessa N, Berhane Y. (2003). Women's Health and life Events study in rural Ethiopia. EJHD.2(7).

Hanrahan P, Cammpbell J, Ulrich Y. Theories of violence, 1993. Cited in Lowdernilk LD, Perry ES, Bobak MI. (2000). Maternity Women's Health Care. (7th ed.). Mosby, St. Louis. P.p. 226-227.

Hassan S, Tariq Q, Niaz U. (2002). Development and validation of Karachi Domestic 
violence screening scale( KDVSS). Pak $J$ Med Sci. 18(3). P.p. 197-204.

Johnson JK, Haider F, Ellis K, Hag DM, Lindow SW. (2003). The prevalence of domestic violence in pregnant women. BJOG. 110(3). P.p. 272

Khairi S. (2006). The effect of Domestic Violence on pregnant women who attend maternity hospitals in Baghdad city. MSc Dissertation, College of Nursing, University of Baghdad, Iraq.

Kuning M, MC Neil D, Chongsuvivtwong V. (2004). Physical abuse during pregnancy. Eur J Gen Med. 1(2). P.p. 610.

Levinson. (2003). Domestic violence in Cross cultural perspective, New Park, 1989. Cited in Gossaye Y, Deyessa N, Berhane Y. Woman's and life events study in rural Ethiopia. EJHD. 17(2).

Lundwall, Jonna, Fons, Teresa, Genta, Sanchez de Boado, Milena. (2009). Domestic violence is a public affair: Strengthening institutions to promote equitable development and combat violence against women in Uruguay. World Bank, Washington. Retrieved from http://openknowledge.worldbank.org/han dle/10986 $=$ on 2012. IVSL(Iraqi Virtual Scientific Library).

Moore AR. (2008). Types of violence against women and factors influencing intimate partner violence in Togo (West Africa). $J$ Fam Viol. 23. P.p. 777-783. IVSL (Iraqi Virtual Scientific Library).

Stuart WG, Laraia TM. (2001). Principles and practice of Psychiatric Nursing. ( $7^{\text {th }}$ ed.) Mosby, St. Louis. 834.

World Health Organization. Iraq family health survey. 2006. Available at http://www.emro.who.int/iraq/ pdfifhsreport-en.pdf=all on 2011.

Yoshi Hama M and Sorenson S. (1994). Physical, sexual and emotional abuse by male intimates: Experiences of women in Japan. Violence and victim. 9. P.p.63-77. 